Nataliya Sergeevna Ivanova,

Master of Sociology

Research Fellow of the

RANEPA's Center for Regional

and Urban Studies

Researcher of the Migration

and Ethnicity Research Group

Moscow, Russia

nataliya.ivanova.0709@gmail.com

Co-authors: Albina Sergeevna Andreeva, Master of international relations, Researcher of the Migration and Ethnicity Research Group, Moscow, Russia formulagerona@gmail.com

Evgeniy Aleksandrovich Varshaver, Candidate of Sociological Sciences, Senior Researcher of the RANEPA's Center for Regional and Urban Studies, Head of migration and ethnicity research group.

Moscow, Russia

varshavere@gmail.com.

DOI 10.31554/978-5-7925-0571-1-2019-2-199-200

\title{
FORMATION OF ZONES OF THE RESIDENTIAL CONCENTRATION OF MIGRANTS IN KOTEL'NIKI (MOSCOW REGION)
}

After the collapse of the Soviet Union Russia began to accept foreign non-ethnic migrants. The resident choice of such migrants in Russia was often determined by the minimum amount of time between the place of work and the place of residence, and one of the typical jobs for such migrants were the markets. As a result, Russia has developed a special pattern of resettlement of migrants, which refers to the residence of a large number of migrants in the vicinity of markets. However, despite the existence of this pattern over the past thirty years, and due to the lack of similar forms of resident concentration in other countries, no good descriptions of this pattern have been produced.

For a long time in Moscow the largest market was Cherkizovsky, which was located in the North-East of the capital. In 2009 it was closed, after what many entre- 
preneurs moved outlets to the South-East of Moscow to another site - the market "Sadovod". Following the transfer of retail facilities, both businessmen and their employees moved. A new place of residence for many migrants was the town of Kotelniki near Moscow, which was experiencing a construction boom at that time. As a consequence, migration processes and moving market workers closer to jobs overlapped with the expansion of a small Soviet city, due to the construction of huge residential complexes. During these events, new buildings in Kotelniki became zones of high concentration of migrants with established emigrant infrastructure ("apartments-hostels", "ethnic" business, realtors specializing in working with migrants). This state of affairs contributes to the further inflow of migrants. The migration and ethnicity research group conducted a study of the formation of zones of resident concentration of migrants in the city of Kotelniki, the results of which will be presented in the report.

Keywords: resident consentration, migrants, markets. 